\title{
Blending a Three-Way Technology into A Language Acquisition and Development Course for Pre-service Teachers
}

\author{
Chih-Feng Chien ${ }^{1, *} \&$ Zahra Moghadasian Rad $^{2}$ \\ ${ }^{1}$ Graduate School of Education, Chung Yuan Christian University, Taoyuan 32023, Taiwan, R. O. C. \\ ${ }^{2}$ Department of Educator Preparation, Houston-Tillotson University, TX 78702, USA \\ Correspondence: Graduate School of Education, Chung Yuan Christian University, Taoyuan 32023, Taiwan, R. O. C. \\ Tel: 886-3-265-6818. E-mail: iorifeng@gmail.com
}

Received: October 14, 2013 Accepted: November 4, $2013 \quad$ Online Published: November 12, 2013

doi:10.5430/jct.v2n2p112 URL: http://dx.doi.org/10.5430/jct.v2n2p112

\begin{abstract}
This article is to report an action research conducted in two sections of a course called Second Language Acquisition and Development during the fall semester of 2011 and the spring semester of 2012. By focusing on a three-way blended learning (BL) environment-face-to-face (F2F), eLearning, and Second Life (SL, a virtual-world environment), this study attempts to explore students' experiences, perceptions, and reflections on multimedia technology and apply the findings to help improve a second language acquisition course. By conducting 36 interviews totally from two semesters (15 from the first semester and 21 from the second semester) as well as 30 course observations (20 F2F and 10 SL observations), the result of the study suggests students preferred the combination of F2F and eLearning. The study concludes that SL application needs to be reevaluated for a better BL instructional structure in terms of student's skills, training, high-standard hardware equipment, and design of virtual installation in order to effectively integrate it into the course of Second Language Acquisition and Development.
\end{abstract}

Keywords: face-to-face; eLearning; second Life; virtual world; second language acquisition

\section{Introduction}

The field of second language acquisition (SLA) burgeoned in the early 1960s (Ellis, 1997). At the same time, computer applications in second language acquisition (CASLA) and computer-assisted language learning (CALL) emerged to explore how computers could be utilized in foreign language learning in higher education (Chapelle, 2001). In the 1970s and 80s, overhead projectors and audio-tapes were the earliest media for drill-and-practice, grammatical exercise and comprehensive listening for language classrooms (Warschauer \& Meskill, 2000). In the late 1980s, computer-mediated communication (CMC) began to popularize the (English as a Second Language) ESL curriculum (Warschauer \& Kern, 2000). By the 1990s the Internet began to influence a variety of perspectives within the field, such as providing access to native or proficient English speakers (Chapelle, 2001). CMC and Internet brought both synchronous (e.g., face-to-face, online chat) and asynchronous (e.g., email, online discussion) applications to SLA learning environments. This was where blended learning (BL) in SLA environments occurred.

With CMC and the Internet developing rapidly in the recent decade, advanced CALL has been integrated into pedagogical goals and techniques by researchers and practitioners (Paramskas, 1999). Online learning management systems (LMSs) are widely used as an online supplemental resource to face-to-face (F2F) classes to train pre-service teachers in the field of education at higher education (Lin, 2008). The integration of F2F and LMS turns the class setting into a blended learning (BL) environment. BL has emerged as an efficient and effective communication medium to enhance the quality of teaching and learning in higher education (Garrison \& Vaughan, 2008). Many training courses for pre-service language teachers have been integrated into a number of LMSs, such as Blackboard and Moodle (Stockwell, 2007).

BL environments usually refer to the combination of "self-paced learning, live eLearning, and face-to-face classroom learning” (Alonso et al., 2005, p. 234). A blended-learning (BL) environment brings the potential enhancement of effectiveness and efficiency among higher education institutions (Garrison \& Kanuka, 2004). Some empirical studies show the benefits of language learning received from a BL environment (e.g., Banados, 2006; Neumeier, 2005; Wang 
\& Chen, 2007).

With the benefits of advanced technologies, virtual worlds (VWs) are emerging as a huge potential platform for teaching and learning (Chodos, Naeimi, \& Stroulia, 2009; Coombs, 2010; Wankel, 2010). As more and more supports and ideas emerge for using a VW in higher education, it is developing rapidly as a part of BL (Yahaya, 2007). Moreover, virtual environments are supported by literature for better protection of privacy for cross-national and cross subject learning (Mascitti, Fasciani, \& Di Marco, 2011). For the reason of anonymity and privacy, this research applies Second Life (SL) — a free registered virtual environment for rich learner engagement, free exploration and construction, and manipulation of virtual objects and structures (Dalgarno \& Lee, 2010; Davis, 2012) — into a synchronous distance blended learning.

The researchers intended to design this study as an action research in order to understand the implications, principles and ideas derived from literature. Two undergraduate courses in a large southwestern public university in the U.S were selected because they were the only Second Language Acquisition and Development courses at the school using a three-way BL environment. The purposes of the study were to explore students' experiences and perceptions of and reflections on a 3-way BL, and conclude suggestions about how multimedia technology can be used in a second language acquisition course.

\section{Literature Review}

\subsection{Technology of Blended Learning}

Neumeier (2005) defines BL as a combination of F2F and computer assisted learning. He posits the purpose of BL is to find the most effective and efficient way to combine these two modes for learning subjects, contexts, and objectives. Sharma (2010) specifies BL environment with three definitions. First, it is an integrated combination of traditional learning and virtual learning environments (Blackboard, Moodle, or bulletin boards). Secondly, BL is also referred to as a distance learning environment where eLearning media and a number of technologies are employed. Thirdly, SL is the inclusion of a present-practice-produce methodology and task-based learning (e.g., constructivist teaching).

Different studies have investigated how BL can benefit students and instructors with a variety of technologies. Allan (2007) divides the tools and technologies of BL into five main groups: "technologies in the classroom; virtual communication tools; social-networking software; eLearning systems; and mobile learning” (p. 15). The technologies in the classroom are those commonly used in F2F learning environments, including PowerPoint, interactive whiteboards, and audience response systems (e.g., clicker). Virtual communication tools are those generally used for online communication, including asynchronous tools (e.g., email, discussion boards, and weblogs), and synchronous tools (e.g., Skype, and videoconferencing). Social-networking sites allow individuals to create a personal website with photographs, text, and bulletins. Allan (2007) specifies eLearning systems, such as Moodle and WebCT, are like a one-stop shop which brings together a wide range of tools for supporting multidisciplinary knowledge and learning experience. Different eLearning systems have different features, but they generally provide discussion groups, chat rooms, online assessment tools, blogs, resource management, and tutor tools. Mobile learning includes hand-held computers and Personal Digital Assistants (PDAs) which allow students to respond and vote in a lecture room.

\subsection{The Use of Blended Learning in Second and Foreign Language Acquisition}

Although a number of studies show that the positive correlation between the use of technology and student achievement in learning foreign or second languages (Egbert, Paulus, \& Nakamichi, 2002; Verdugo \& Belmonte, 2007), very few focus on the integration of technology applications and teacher preparation programs for teachers of English to speakers of other languages (TESOL) (Honigsfeld, Giouroukakis, Cohan \& Walsh, 2009; Kassen, Lavine, Murphy-Judy, \& Peters, 2007). In addition, despite BL being commonly utilized in the teacher preparation for TESOL, few empirical studies have been conducted in this field (e.g., Kupetz \& Ziegenmeyer, 2006). The following section is a review of some selected studies from a handful of research.

In teacher preparation courses, instructors and practitioners considerably utilize slideshow software and interactive whiteboards in F2F classes (Honigsfeld, Giouroukakis, Cohan, \& Walsh, 2009). O’Bryan and Hegelheimer's (2007) study reveals that podcasting allows visual and audio immersion via the Internet to expand educational context of the classroom. Synchronous conferencing systems bring in more simultaneous interactions for language teacher training in a distant part of BL (Hampel \& Hauck, 2004). Moreover, computer assisted learning incorporated into a BL environment provides effective functions (e.g., introducing new topics into virtual chatting) for language teacher 
training and preparation (Neumeier, 2005).

Another study on BL applied in the course of technology and language learning for pre-service and in-service teachers provides a case study showing the advantages of BL tools (Hoven, 2006). These tools refer to reflective and social computing tools, such as online chatting, blogs, wikis and e-portfolios, and task programs. With a three-semester follow-up longitudinal study for a master's course, all the technological tools and processes for language teaching were modeled and experienced by the teacher students. The course successfully applied the BL approach on creative language teaching with technology, such as Computer Enhanced Language Learning (CELL), interactive eLearning, social networking, and multimedia. In this BL environment, these teacher students discovered the effective role that technology plays in language teaching and learning.

\subsection{Second Life and Its Use for Second and Foreign Language Acquisition}

When virtual worlds advance to Second Life (SL), it draws a lot of attention in a variety of fields, such as science (Bainbridge, 2007; Rodger, 2002), marketing (Ward, 2010), foreign language study (Wang et al., 2010), etc. SL is a 3D virtual world launched in 2003 and developed by Linden Labs. It is an online, visually immersive environment where multi-users interact and collaborate through mobile avatars. SL is full of visualization, imagination, and innovation, such as shaping avatar's appearance, creating objects, teleporting from one site to another, and owning virtual properties (Mohammed, 2009).

There are a few examples about how SL has been recently used in second language and foreign language acquisition. Henderson et al. (2009) observed how Australian university students learned Chinese language in SL. Wang et al. (2010) used SL to teach a collaborative course at Yantai University in China and Georgia State University in the USA. However, there are very few cases integrating SL into BL in TESOL teacher preparation.

\section{Methodology}

\subsection{Research Approach}

This study was designed and constructed as an action research in order to understand the selected course's situation for teaching and learning improvement. Armstrong and Moore (2004) posit that an action research is designed for a classroom in order to monitor instructional practices, examine social and cultural transformations, and negotiate feasible ways for improving classroom setting. Action research is conducted by practitioners in order to improve their teaching and learning (Glanz, 1998). Rohleder, Swartz, Bozalek, Carolissen, and Leibowitz (2008) addressed that action research can be used to investigate the learning context, provide feasible solutions for problematic issues and improve practitioners' practices. The benefits of conducting an action research are to enhance decision making for teaching contexts, to promote practitioner's self-reflection and self-assessment, to create a more positive classroom climate for teaching and learning, and to impact directly on classroom practices (Glanz, 1998).

In order to further improve the BL environment used in the preparation of pre-service language teachers, this study is to explore an experimental three-way BL environment from two semesters. Because the result of first semester only indicates the need for major adjustment in SL, researchers decided to modify the SL portion for the second semester; other course contents remain unchanged. Two semesters decided to consider as an action research as a whole for more in-depth investigation. The purposes of this study are twofold: to investigate how a three-way multimedia BL environment can be utilized in a language acquisition course for pre-service teachers, and to improve the course by analyzing their perceptions of and reflections on the 3-way BL. To achieve these purposes of the study, the following research questions are explored:

1. What are students' experiences with the instructional structure of blended-learning environment in the second language acquisition course?

2. What are students' perceptions of the distance tools-eLearning (referring to the learning management system—Blackboard) and Second Life in a BL course?

\subsection{Course Description}

For evaluating 3-way BL, the course selected for the study was Second Language Acquisition and Development for teacher students. Although the course has been mainly designed for education majors, students in other disciplines who were interested in a possible future teaching career could take it. A number of instructors teach different sections of this course during a semester. The sample course the researchers chose for both studies consisted of two sections taught by the same instructor during the fall semester of 2011 and spring semester of 2012. The course instructor is the second author of this study, so she understood the research objectives and why conducting an action research 
would improve the instruction and course design.

The course contents include the following components:

1. Covering 11 chapters of a book, entitled "Reading, writing and learning in ESL: A resource book for teaching K-12 English learners” (Peregoy \& Boyle, 2008). The chapters were covered in F2F classes (60\%), Blackboard learning system (20\%), and SL classes (20\%) during the semester.

2. Students were put in groups of $4-5$ and were asked to mock teach a class that had at least $30 \%$ ESL students.

3. Posting to five discussion boards based on five articles covering ESL issues. The articles were already posted on Blackboard. Every student would post at least two times for every single discussion board. The postings could be a comment based on the assigned article, a question, or an answer to a question already posted by another student.

4. Ten hours of either observing assigned English language classes at the University's English Language Institute (ELI) or of meeting a conversation partner who was a language learner at ELI. The students were required to fill a rubric and write down comments when observing an ELI class or when meeting a conversation partner. They would also write a two-page reflection paper on this experience at the end of the semester. The students who opted for observing ELI cases would sign up an attendance sheet in ELI classes. For those who preferred to have an individual conversation partner, they would sign up and date an attendance sheet every time they met with their partners.

5. Both a mid-term exam and a final exam consisting of 40 multiple-choice items used to evaluate students' achievement in the course. The mid-term exam covered chapters 1-5 and the final exam covered chapters 6-11. The mid-term exam was worth $25 \%$ of the course grade and the final $15 \%$.

6. Global Classroom Project for which students were assigned to meet language learners in a virtual coffee shop, called "Caddy Shack" in SL. Hosted by the Teaching and Learning Centre of a University in Hong Kong, this project facilitated the interaction of language learners (Chinese undergraduate students) with education majors (Texas undergraduate students) who were learning how to teach language learners. The objective of this virtual activity was to increase Chinese students' opportunities to practice English in real-life situations with native English speakers and for American students to practice teaching ESL students and learn about Eastern cultures.

The course syllabus for the second semester was exactly the same as the first semester except for the virtual project. Instead of Global Classroom Project, during the spring semester of 2012 the class instructor sent an e-mail to an SL listserv called SL Educators (SLED) and asked the other subscribers if anybody was interested in collaboration within SL. The goal was to provide the students with opportunities to practice their SL skills while working on the course content. A professor from a university in Pennsylvania responded with a class with 12 graduate students registered in a course called Emerging Technology and Global Collaboration. The two instructors met in SL and, after sharing their syllabi, they decided what activities their students were required to accomplish in SL (Figure 1).

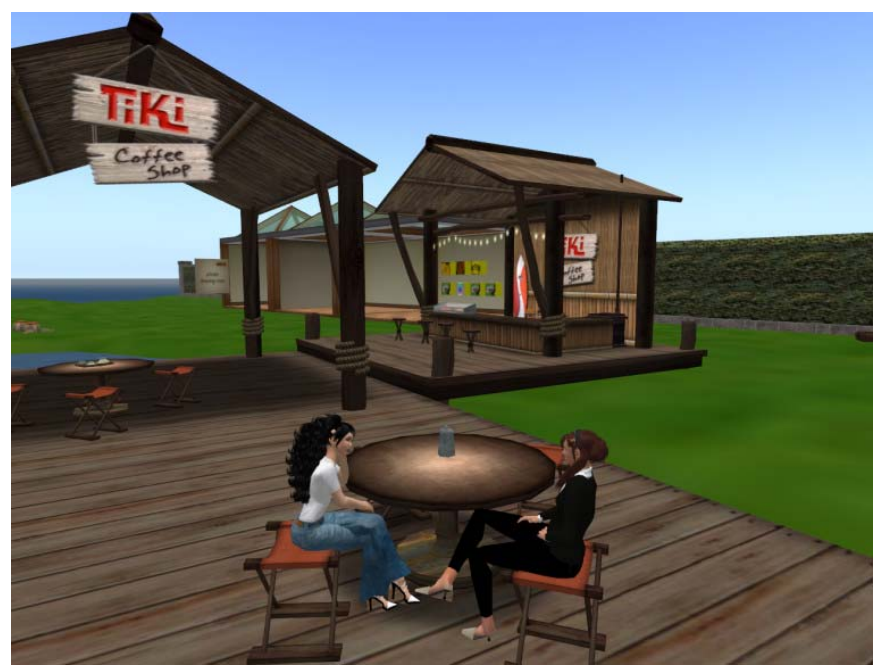

Figure 1: The Two Instructors Meeting in SL

For SL session, in the 2011 fall semester, students from Texas and Hong Kong were listening to the professor's 
lecturing for around 20 minutes on the topics of applying technology in teaching English as second language. Students from both sides then divided into 10 groups with 3 to 4 members each to discuss the topics. Because students from Texas were bothered with the issues of different time zones and Chinese students' accents, the SL session was decided to switch back to the USA in the second semester.

In the 2012 spring semester, students from two Texas and Pennsylvania were divided into 12 groups, and each group was paired up with one graduate student (Pennsylvania) leading eight to nine undergraduate students (Texas). All groups were required to read the same assigned articles and watch video clips on the application of emerging technologies in ESL education, how virtual worlds are in general, and how SL could be used to help ESL students. Then they would meet in SL, discuss the assigned articles/clips and post to eLearning discussion boards. All groups were required to have at least three 1.5-hour virtual meetings throughout the semester. Because no data were collected from the graduate students in Pennsylvania, no information on these students is included in this study.

For overall course description and relation from two semesters, please see Figure 2 below.

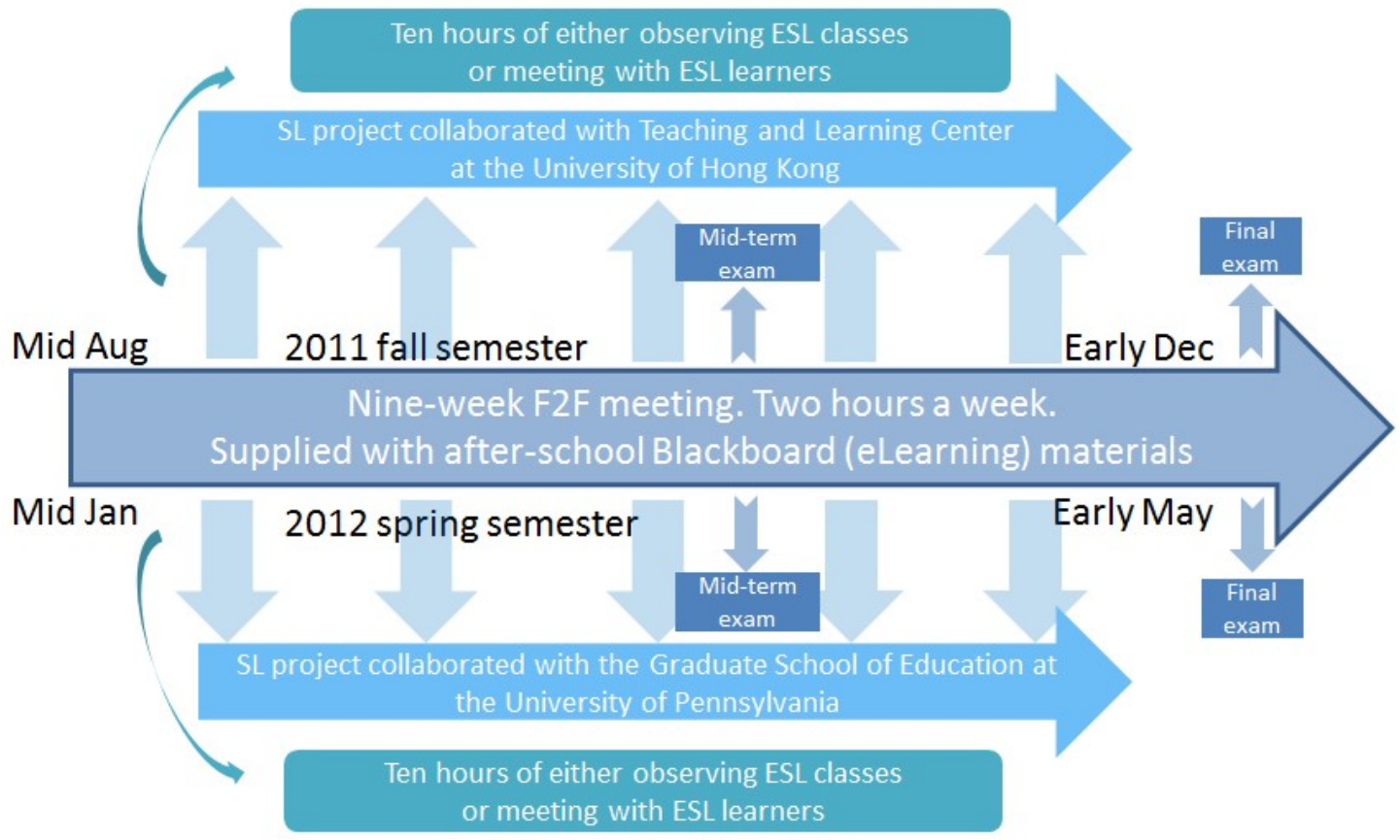

Figure 2: Course Description and Its Components

\subsection{Participants}

In this study, 15 ( 2 males and 13 females) out of 97 students from 2011 fall semester and 21 ( 3 males and 18 females) out of 105 students from 2012 spring semester volunteered to participate in interview. Each participant was given a small Asian artifact to appreciate their time.

\subsection{Data Collection}

The data sources include 30 class observation reports and 36 interviews from two semesters. First, the observation data were recorded using a field note protocol and conducted on a number of sessions in which students engaged in SL activities or discussed mainly their BL experiences. Totally 20 class observations and 10 SL observations were collected for the study from two semesters. Observation notes provided the detailed records of the two semesters' course activities, including F2F and virtual interactions. The F2F observation notes were taken by one of the researchers during the F2F sessions. The virtual observations were recorded using the Camtasia program-a screen-capture software, and were later reviewed and written as reports by the other researcher. The interactions (student-student, student-instructor, and student-distance graduate students) within F2F classes and SL sessions were the main focus to be captured (Appendix A \& B). Secondly, interviews were conducted at the end of each semester in order to investigate students' perceptions of 3-way BL and multimedia technology application. Thirty-six interviews were conducted (15 from 2011 fall semester and 21 from 2012 spring semester). The interview protocol consisted of 20 open questions (Appendix C), some of them included sub-questions. Some questions were extended according to 
the interviewees' responses in order to obtain complete information. The form of semi-structured interview with a list of questions and prompts were adopted in order to cover comprehensive topics (DeWalt \& DeWalt, 2002). Time spent on each interview ranged from 30 to 45 minutes, all audio-taped with interviewees' permission. Interviewers also jotted down the research notes in order to record every interviewee's characteristics, facial expressions, gestures, body language, etc. The researchers served as the primary instruments for conducting interviews and data analyses (Merriam, 1998).

\subsection{Data Analysis}

By using Lincoln and Guba's (1985) content analysis approach, the researchers coded transcriptions of audio-taped interviews and videotaped observations, identified emerging themes, and categorized the individual categories. As DeWalt and DeWalt (2002) described, this was a process of "data reduction," which refers to selecting, simplifying, and reducing huge amounts of text to manageable contents. Then, the researchers conducted indexing-an approach to develop the descriptive codes (DeWalt \& DeWalt, 2002)—on field notes and interviews during the act of data collection (see Appendix C for interview questions). During the period that the data was collected and analyzed, some ambiguous data interpretations were brought back to the participants in order to clarify if the interpretations were plausible. This process is referred to member checking (Merriam, 2002).

\section{Results and Discussion}

\subsection{Students' Experiences of Blended Learning}

The majority of participants from both semesters' studies preferred a two-way BL learning environment, though a few said three-way BL was good for different learning styles. Most of them thought BL (either two-way or three-way) was convenient and supplementary to one another. Some of the participants also enjoyed learning about advanced technology. However, the majority of them expressed their dislike for learning SL as another technological skill they had to master. Participants believed SL assignments were difficult to complete because of scheduling and technical issues, the fact that they were time-consuming, etc. Besides, students who disliked eLearning thought personal interaction was an important element in F2F class, which was missing in asynchronous classes (see Table 1).

Table 1: Comparison of the Themes Coded from Two Semesters on Students' Experiences with BL

\begin{tabular}{|c|c|c|}
\hline $\begin{array}{l}\text { Categories } \\
\text { (\%) Response rate }\end{array}$ & $\begin{array}{l}\text { Themes (2011 Fall) } \\
\text { 1st semester }(n=15)\end{array}$ & $\begin{array}{l}\text { Themes (2012 Spring) } \\
\text { 2nd semester }(\mathrm{n}=21)\end{array}$ \\
\hline Benefits of $B L$ & $\begin{array}{l}\text { Convenient (80\%) } \\
\text { Supplementary materials (85\%) } \\
\text { Learning about technology (60\%) }\end{array}$ & $\begin{array}{l}\text { Supplementing other forms of teaching } \\
(82 \%) \\
\text { Good for different learning styles (69\%) }\end{array}$ \\
\hline Weakness of BL & No enough personal interaction (82\%) & $\begin{array}{l}\text { Excessive amount of reading (47\%) } \\
\text { Duplicated contents (48\%) }\end{array}$ \\
\hline
\end{tabular}

\subsection{Students' Perceptions of eLearning Classes}

The data collected from two semesters indicate that the participants had positive attitudes toward eLearning (see Table 2). The participants from 2011 fall semester unanimously agreed eLearning was user-friendly in terms of technological skills because of their experience with using eLearning in many courses and the way eLearning organizes content. They considered eLearning as an advantageous platform providing supplementary materials to F2F classes. On the other hand, some participants believed lack of interactivity, facilitating cheating and technical issues especially during exams were some of the disadvantages of eLearning.

Nassie70 (SL avatar’s name) from the second semester share her opinions about eLearning.

Two problems I have with eLearning. When it is down, I am not able to access my work for my classes, you know, when maintenance is being down on the system. Also, I feel I like to talk with classmates and teacher in the class. On eLearning, I could not do that (Nassie70, April 15, 2012).

The findings from two semesters reveal a number of overlapping themes based on the data analysis, such as asynchronous discussions and supplementary course materials, which benefited students to learn beyond F2F classes.

However, the data from the 2012 spring semester shows more in-depth responses from the participants' viewpoints. The participants in 2nd semester considered eLearning as another social networking to easily remember classmates' 
names and communicate by sending instant messages. They also stated some shy students were more willing to engage in group discussions in eLearning's discussion boards because it is less threatening than speaking in front of others. Online exam was another advantage of eLearning because the participants could self-schedule to take exams at their own convenience. Furthermore, feedback on homework and grades could be immediately released through eLearning.

\subsection{Students' Perceptions of Second Life classes}

Based on Table 2, in regard to the advantages of SL, half of the participants from the 2011 fall semester believed SL was interesting and entertaining because of its visual and auditory richness. SL also enabled them to meet people and visit places from across the world. The participants from the 2012 spring semester considered SL as a platform to support eLearning in terms of its synchronous distance meeting.

As for negative perspectives, the participants from the 1st semester indicated their frustration with SL activities due to class scheduling issues and SL skill training. Based on the interview data, their biggest frustration with SL was the online workshops. One of the course requirements was to attend the Hong Kong workshops in SL.

MarmahanAF (SL avatar's name) from first semester talked about his frustration with SL.

I feel like we did not use Second Life that much. I personally did not like it because my laptop at home is a bit older, like four years. Second Life ran really slow. Also the scheduling [of Second Life project], because we need to get up [for the workshop] from six to eight in the morning, it is very inconvenient (MarmahanAF, November 10, 2011).

Since America and Hong Kong are in two different time zones, the 9pm workshops in Hong Kong would be at 6am for American students. Thus, in the 2nd semester, the researchers modified the SL assignments to solve the extreme time zone difference. In the 2nd semester, the students were required to meet with graduate students at a University in Pennsylvania with a one-hour time zone difference. However, the participants from 2nd semester still addressed the inconvenience for scheduling three 1.5-hour virtual meetings throughout the semester.

There are other SL weaknesses as stated. The participants from the 1st semester expressed their concerns with SL, such as the difficulty of learning the basic SL skills, high hardware requirements, and the need for wired connection with a broad internet bandwidth. The participants from the 2nd semester believed SL could be replaced with user-friendly and low-memory-usage software, such as Skype. They also indicated their frustration with being accosted by random strangers and distracted by irrelevant contents in-world. The majority of the participants considered SL as an additional technology learning beyond F2F classes and eLearning. The time spent on learning the basic SL skills was considerable. In addition, they found it was difficult for them to apply SL into K-12 settings.

Observation reports show that in the first semester students tended to remain silent when teacher was lecturing. In the second semester, students were more engaged because those were discussion group meetings. Some avatars were running all the way off the screen or having hard time trying to do something, resulting obviously from technical issues. The positive side was, as observed throughout the second semester, discussion sessions seemed to be engaging.

\subsection{Students' Perceptions of Face-To-Face Classes}

The data from 2011fall semester indicated all interviewees (100\%) preferred traditional F2F classes. They enjoyed the interactivity in F2F classes which they believed was missing in eLearning or SL. They also indicated F2F classes were more humanized compared to eLearning and SL. They perceived the in-class learning and experiences were irreplaceable. The majority of the participants from the 2012 spring semester thought F2F classes provided both verbal and non-verbal interactions and hands-on activities. In addition, the social interaction was the important reasons to have a F2F class.

However, the participants from the 2011 fall semester complained F2F classes were normally boring and that unless attendance was forced, the attendance rate would be very low. Furthermore, the participants from the 2012 spring semester argued about the repetitive contents taught in both F2F and eLearning. Moreover, some students would be unwilling to share or discuss ideas in F2F classes because they were afraid of being judged by classmates or speak in front of others.

Observation reports indicate that majority of students engaged in F2F class discussions. As one of the researchers observed the instructor was great at asking questions. Students- student and instructor-student interactions seemed very engaging. 
Table 2: Comparison of the Themes Coded from Two Semesters on Students' Perceptions in the Three-Way Blended Learning Environment

\begin{tabular}{|c|c|c|}
\hline $\begin{array}{l}\text { Categories } \\
\text { (\%) Response rate }\end{array}$ & $\begin{array}{l}\text { Themes }(2011 \text { Fall }) \\
\text { 1st semester }(\mathrm{n}=15)\end{array}$ & $\begin{array}{l}\text { Themes (2012 Spring) } \\
\text { 2nd semester }(\mathrm{n}=21)\end{array}$ \\
\hline $\begin{array}{l}\text { Advantages of } \\
\text { eLearning }\end{array}$ & $\begin{array}{l}\text { Convenient and accessible (93\%) } \\
\text { Organized (71\%) } \\
\text { Easy }(100 \%)\end{array}$ & $\begin{array}{l}\text { Immediate grade release (80\%) } \\
\text { Online materials (95\%) } \\
\text { Easy communication (70\%) } \\
\text { Self-scheduling (88\%) } \\
\text { Online assessment (80\%) } \\
\text { Discussion boards (98\%) } \\
\text { Remembering classmates (55\%) }\end{array}$ \\
\hline $\begin{array}{l}\text { Disadvantages of } \\
\text { eLearning }\end{array}$ & $\begin{array}{l}\text { Not interactive enough }(61 \%) \\
\text { Cheating prone }(15 \%) \\
\text { Computer phobia (47\%) } \\
\text { Technical issues (50\%) }\end{array}$ & $\begin{array}{l}\text { No in-person interaction (85\%) } \\
\text { Not very inviting/interesting (30\%) }\end{array}$ \\
\hline Advantages of $S L$ & $\begin{array}{l}\text { Interesting and entertaining (42\%) } \\
\text { Easy to meet/see other } \\
\text { people/places (25\%) }\end{array}$ & $\begin{array}{l}\text { Synchronous distance meeting (90\%) } \\
\text { Advanced technology }(85 \%) \\
\text { Virtual reality (88\%) }\end{array}$ \\
\hline Disadvantages of SL & $\begin{array}{l}\text { Difficult to learn the skills (91\%) } \\
\text { No educational value (95\%) } \\
\text { Freaky (83\%) } \\
\text { Unfamiliar (96\%) } \\
\text { Wideband issues (93\%) } \\
\text { Technical issues (95\%) }\end{array}$ & $\begin{array}{l}\text { Random socialization (78\%) } \\
\text { Irrelevant content (70\%) } \\
\text { Additional technology learning (85\%) } \\
\text { Additional learning (88\%) } \\
\text { Time-consuming to learn SL skills } \\
\text { (90\%) } \\
\text { Cannot apply to K-12 settings (60\%) } \\
\text { Many trial and error processes (55\%) }\end{array}$ \\
\hline Advantages of F2F & $\begin{array}{l}\text { Interactive }(100 \%) \\
\text { Humanized }(82 \%) \\
\text { Structured (48\%) } \\
\text { No confusion }(75 \%) \\
\text { In class learning }(94 \%)\end{array}$ & $\begin{array}{l}\text { Non-verbal interaction (80\%) } \\
\text { Hands-on activities (85\%) } \\
\text { Social engagement (85\%) }\end{array}$ \\
\hline Disadvantages of F2F & $\begin{array}{l}\text { Boring (57\%) } \\
\text { Obligatory attendance (88\%) }\end{array}$ & $\begin{array}{l}\text { Repetitive content (45\%) } \\
\text { Difficult to speak in public (25\%) }\end{array}$ \\
\hline Challenges of $S L$ & $\begin{array}{l}\text { Need more training ( } 85 \%) \\
\text { Small portion of course grade }(45 \%)\end{array}$ & $\begin{array}{l}\text { Being trained is time-consuming ( } 92 \%) \\
\text { Big portion of course grade }(40 \%)\end{array}$ \\
\hline
\end{tabular}

\subsection{Contradictory Data Results and Suggestions}

The researchers realized the participants had contradictory perspectives on a couple of issues. In the 1st semester some students claimed allocating only $10 \%$ of the course grade to SL activities was not big enough of an incentive for them to invest their time to complete SL activities. However, some of the participants from 2nd semester believed it was unfair to allocate $10 \%$ of the course grade to SL activities and that if they failed to attend their SL meetings or complete their SL activities just because of technical issues, they would automatically fall to grade B.

Another contradictory finding was regarding how much SL training the students needed. The participants from 1st semester were concerned about insufficient training to master SL skills. However, after the instructor's modification for more training, some of the participants in the 2nd semester were dissatisfied with the extra time they had to invest to learn SL skills.

For future pedagogical implementation on three-way BL, we created Table 3 to summarize suggestions on using 3-way BL was created as below. 
Table 3: Recommendations for the Three-Way Blended Learning Environment

\begin{tabular}{|c|c|c|c|}
\hline Categories & $\begin{array}{l}\text { 1st semester } \\
(2011 \text { Fall })\end{array}$ & $\begin{array}{l}\text { 2nd semester } \\
\text { (2012 Spring) }\end{array}$ & Recommendations \\
\hline $\begin{array}{l}\text { Second Life } \\
\text { training }\end{array}$ & $\begin{array}{l}\text { Students stated they did } \\
\text { not receive enough } \\
\text { training }\end{array}$ & $\begin{array}{l}\text { Students received } \\
\text { enough training but } \\
\text { complained it was time } \\
\text { consuming to master SL } \\
\text { skills. }\end{array}$ & $\begin{array}{l}\text { Instructors can design video } \\
\text { tutorials or in-world } \\
\text { orientations for SL training. } \\
\text { Points can be allocated to } \\
\text { mastering and demonstrating } \\
\text { basic SL skills. }\end{array}$ \\
\hline $\begin{array}{l}\text { Equipment } \\
\text { adjustment }\end{array}$ & $\begin{array}{l}\text { Most students had to } \\
\text { use their own } \\
\text { computers because the } \\
\text { workshops were held } \\
\text { early in the morning. }\end{array}$ & $\begin{array}{l}\text { Students could use } \\
\text { computer labs. However, } \\
\text { they were still concerned } \\
\text { about SL's high hardware } \\
\text { requirements. }\end{array}$ & $\begin{array}{l}\text { The Linden Labs should } \\
\text { decrease hardware } \\
\text { requirements. Instructor can } \\
\text { collaborate with Tech Service } \\
\text { for evaluating students' } \\
\text { computers to meet SL } \\
\text { requirements. Also students } \\
\text { can check out laptops from } \\
\text { Tech Service. }\end{array}$ \\
\hline Class meeting & $\begin{array}{l}\text { Students were meeting } \\
\text { language learners from } \\
\text { a university in Hong } \\
\text { Kong university }\end{array}$ & $\begin{array}{l}\text { Students were meeting } \\
\text { graduate students from a } \\
\text { university in } \\
\text { Pennsylvania }\end{array}$ & $\begin{array}{l}\text { Suggest assigning class time } \\
\text { for students to meet } \\
\text { counterparts. For example, if } \\
\text { students need to meet } \\
\text { counterparts one hour a week, } \\
\text { reduce an hour class time to } \\
\text { make up for the meeting time. } \\
\text { Some classes can meet in SL } \\
\text { so that students can get used to } \\
\text { SL meetings. }\end{array}$ \\
\hline $\begin{array}{l}\text { Technology } \\
\text { preparation }\end{array}$ & $\begin{array}{l}\text { Instructor created word } \\
\text { document instructions } \\
\text { for students to learn SL } \\
\text { basic skills. Most } \\
\text { students did not read } \\
\text { instructions. }\end{array}$ & $\begin{array}{l}\text { Instructor took the } \\
\text { students to a computer } \\
\text { lab weekly and trained } \\
\text { them on SL skills but } \\
\text { they would not practice } \\
\text { on their own to master } \\
\text { the skills }\end{array}$ & $\begin{array}{l}\text { Students can be required to } \\
\text { complete some individual } \\
\text { activities designed in SL to } \\
\text { make sure they practice every } \\
\text { week. }\end{array}$ \\
\hline
\end{tabular}

4.6 Why and Why Not Use Three-Way BL

Blended learning is a new trend of education combining traditional teaching and learning as well as technological applications. Second Life is a new alternative to add synchronous distance education into this trend of technology. Many studies have discussed traditional two-way BL (e.g., Neumeier, 2005; Allan, 2007; Dziuban \& Picciano, 2007), so this study will not address much on traditional BL. As to SL addition, the literature review section has emphasized the advantages of adding SL into BL, such as visualization, immersion, simulation, imagination, and innovation; those are the motives why this study promotes three-way BL courses.

However, a few shortcomings of this approach to teaching and learning need to be address. Taylor, Taylor, Kulendran, Gately, and Darzi (2013) identified a couple of barriers including limited access to computers for target samples and the challenge of navigation. In our study, students did complain that their computers could not afford the high hardware standards SL requires (such as in the first semester). Due to time zone differences, they had no access to computers on campus during early morning SL sessions, which resulted in their dislike for SL. A steep learning curve on SL skills was another issue for the students. They had many challenges navigating in SL because they did not practice as much as they were supposed to. These scenarios correspond with Warburton's (2009) conclusion about SL barriers. He argued that technical issues like bandwidth, hardware, and firewalls often lead to "lag" — where heavy loads in a computing system slow virtual world displaying (Warburton, 2009). Time consuming is another issue the students in our study experienced because they needed to spend considerable time to get familiar with the interfaces, 
communication skills and navigation in SL. Culture issue is a minor problem as few students mentioned about security problem because they sometimes were disturbed by strangers or intruder for unreasonable demands.

Three-way BL with SL as the third component provides a number of new potentials as well as obstacles. Instructors of language acquisition and development courses who intend to immerse students with the opportunities of teaching language learning need to weight out the pros and cons in order to manage the new adoption for a visualized environment. As this research concludes advances and weaknesses on the usability of three-way BL, educators may determine the applicability by taking different educational contexts into consideration.

\section{Conclusion}

This study was structured as an action research study with data collected from two semesters. The data from both semesters were compared and contrasted with the purpose of improving future curriculum and instruction in a language acquisition course. Two sets of data were triangulated on the basis of 36 qualitative interviews and multiple observations. The participants agreed multiple-way blended learning can be helpful to teach language learners. However, technical difficulties, scheduling issues, and the steep learning curve for SL caused the students would rather learn the course content in a F2F/eLearning blended learning setting than in a three-way BL environment.

A few underscored points appearing in participants' responses need to be addressed. The participants stated their classmates were more verbal in SL discussions. However, they would still prefer F2F classes to virtual ones. The participants' also found SL assignments and activities interesting and fun but their frustrations- the issues of steep learning curve, technical difficulties, and scheduling - were the key reasons for them to dislike SL. In addition, a number of students disliked the mandatory assignments and requirements for both SL and F2F classes. Researchers concluded the variable of students' learning motivation needs to be taken into consideration. If the instructor increases SL portion, the issue of steep learning curve should be solved because students are able to learn SL basic skills when the instructor reminds them over and over again. In addition, students will appreciate if the instructor reduces class time for making up their meeting with counterparts and facilitating students' scheduling with counterparts. This way, the scheduling issues shall be solved. Moreover, instructors should be responsible to look for resources to fulfill the standard requirements. This issue can be solved if a school technology service is negotiable for students to check out equipment for SL activities.

This study is an initiation of three-way BL as an action research study in a second language acquisition and development course. Unsurprisingly, many unexpected difficulties occurred in this experimental trial. By using an action research approach, the findings and suggestions can inform further ESL course redesigning and refining. Ultimately, the solutions to the challenges of three-way BL are expected to reach multiple subjects. Besides, the possibility of integrating SL activities still needs to be explored, investigated, and finally properly applied.

\section{References}

Allan, B. (2007). Blended learning: Tools for teaching and training. London, UK: Facet Publishing.

Alonso, F., López, G., Manrique, D., \& Viñes, J. M. (2005). An instructional model for web - based e - learning education with a blended learning process approach. British Journal of Educational Technology, 36(2), 217-235. http://dx.doi.org/10.1111/j.1467-8535.2005.00454.x

Armstrong, F., \& Moore M. (2004). Action research for inclusive education: Changing places, changing practices, changing minds. New York, NY: Routledge.

Bainbridge, W. S. (2007). The scientific research potential of virtual worlds. Science, 317(5837), 472-476. http://dx.doi.org/10.1126/science.1146930

Banados, E. (2006). A blended-learning pedagogical model for teaching and learning EFL successfully through an online interactive multimedia environment. CALICO Journal, 23(3), 533-550.

Chapelle, C. (2001). Computer applications in second language acquisition: Foundations for teaching, testing and research. New York, NY: Cambridge University Press.

Chodos, D., Naeimi, P., \& Stroulia, E. (2009). An integrated framework for simulation-based training on video and in a virtual world. Journal of Virtual Worlds Research, 2(1), 3-28. http://dx.doi.org/10.4101/jvwr.v2i1.375

Coombs, G. (2010). Using Second Life for teaching management of creativity and innovation. In C. Wankel (Ed.), Cutting-edge social media approaches to business education: Teaching with Linkedln, Facebook, Twitter, 
Second Life, and Blogs (pp. 141-158). Charlotte, NC: Information Age Publishing, Inc.

Dalgarno, B., \& Lee, M. J. (2010). What are the learning affordances of 3-D virtual environments? British Journal of Educational Technology, 41(1), 10-32. http://dx.doi.org/10.1111/j.1467-8535.2009.01038.x

Davis, T. J. (2012, in press). Mathematics learning in virtual worlds: Affordances and accessibility. In C. R. Reynolds, K. J. Vannest, \& E. Fletcher-Janzen (Eds.), Encyclopedia of special education: A reference for the education of children, adolescents, and adults with disabilities and other exceptional individuals (4th ed.). Hoboken, NJ: John Wiley and Sons.

DeWalt, K. M., \& DeWalt, B. R. (2002). Participant observation: A guide for fieldworkers. Walnut Creek, CA: Altamira Press.

Egbert, J., Paulus, T. M., \& Nakamichi, Y. (2002). The impact of CALL instruction on classroom computer use: A foundation for rethinking technology in teacher education. Language Learning and Technology, 6(3), 108-126.

Ellis, R. (1997). SLA research and language teaching. Oxford, UK: Oxford University Press.

Garrison, D. R., \& Kanuka, H. (2004). Blended learning: Uncovering its transformative potential in higher education. The Internet and Higher Education, 7(2), 95-105. http://dx.doi.org/10.1016/j.iheduc.2004.02.001

Garrison, D. R., \& Vaughan, N. D. (2008). Blended learning in higher education: Framework, principles, and guidelines. San Francisco, CA: Jossey-Bass.

Glanz, J. (1998). Action research: An educational leader's guide to school improvement. Norwood, MA: Christopher-Gordon Publishers, Inc.

Hampel, R., \& Hauck, M. (2004). Towards an effective use of audio conferencing in distance language courses. Language Learning \& Technology, 8(1), 66-82.

Henderson, M., Huang, H., Grant, S., \& Henderson, L. (2009). Language acquisition in second life: Improving self-efficacy beliefs. Actes Ascilite, 464-474.

Honigsfeld, A. Giouroukakis, V., Cohan, A., \& Walsh, M. (2009). Ten ways to incorporate technology into a TESOL teacher preparation program. Contemporary Issues in Technology and Teacher Education, 9(2), 208-221.

Hoven, D. (2006). Designing for disruption: Remodelling a blended course in technology in (language) teacher education. Paper presented at the Twenty-third Annual Conference of the Australasian Society for Computers in Learning in Tertiary Education 2006: Whose learning? Whose technology? Sydney, Australia.

Kassen, M. A., Lavine, R. Z., Murphy-Judy, K., \& Peters, M. (2007). Preparing and developing technology-proficient L2 teachers. San Marcos, TX: The Computer Assisted Language Instruction Consortium.

Kupetz, R., \& Ziegenmeyer, B. (2006). Flexible learning activities forstering autonomy in teaching training. ReCALL, 18(1), 63-82.

Lin, H. (2008). Blending online components into traditional instruction in pre-service teacher education: The good, the bad, and the ugly. International Journal for the Scholarship of Teaching and Learning, 2(1), 1-14.

Lincoln, Y. S., \& Guba, E. G. (1985). Naturalistic inquiry. Beverly Hill, CA: Sage.

Merriam, S. B. (1998). Qualitative research and case study applications in education. San Francisco, CA: Jossey-Bass.

Merriam, S. B. (2002). Assessing and evaluating qualitative research. In S. B. Merriam, \& Associates (Eds.), Qualitative research in practice. New York, NY: Jossey-Bass.

Mohammed, M. R. (2009). Cultural identity in virtual reality (VR): A case study of a Muslim woman with hijab in Second Life (SL). Journal of Virtual World Research, 2(2), 1-10.

Neumeier, P. (2005). A closer look at blended learning — parameters for designing a blended learning environment for language teaching and learning. ReCALL, 17(02), 163-178. http://dx.doi.org/10.1017/S0958344005000224

O'Bryan, A., \& Hegelheimer, V. (2007). Integrating CALL into the classroom: the role of podcasting in an ESL listening strategies course. ReCALL, 19(2), 162-180. http://dx.doi.org/10.1017/S0958344007000523

Paramskas, D. M. (1999). The shape of computer-mediated communication. In K. Cameron (Ed.), CALL: Media design and applications (pp. 13-34). Lisse: Swets \& Zeitlinger.

Peregoy, S. F., \& Boyle, O. F. (2008). Reading, writing, and learning in ESL: A resource book for K-12 Teachers (5th 
ed.). Upper Saddle River, NJ. Pearson/Allyn and Bacon.

Prensky, M. (2001). Digital natives, digital immigrants. In J. J. Hirschbuhl, (Ed.), Computers in Education (pp. 2-4). Dubuque, IA: McGraw-Hill Contemporary Learning Series.

Rodger, S. H. (2002). Introducing computer science through animation and virtual worlds. ACM SIGCSE Bulletin, 34(1), 186-190. http://dx.doi.org/10.1145/563517.563411

Rohleder, P., Swartz, L., Bozalek, V., Carolissen, R., \& Leibowitz, B. (2008). Community, self and identity: Participatory action research and the creation of a virtual community across two South African universities. Teaching in Higher Education, 13(2), 131-143. http://dx.doi.org/10.1080/13562510801923187

Sharma, P. (2010). Blended learning. ELT Journal, 64(4), 456-458.

Stockwell, G. (2007). A review of technology choice for teaching language skills and areas in the CALL literature. ReCall, 19, 105-120. http://dx.doi.org/10.1017/S0958344007000225

Verdugo, D. R., \& Belmonte, I., A. (2007). Using digital stories to improve listening comprehension with Spanish young learners of English. Language Learning and Technology, 11(1), 87-101.

Wang, C. X., Song, H., Stone, D. E., \& Yan, Q. (2010). Integrating Second Life into an EFL program in China: Research collaboration across the continents. TechTrends, 53(6), 14-19. http://dx.doi.org/10.1007/s11528-009-0337-z

Wang, Y., \& Chen, N. S. (2007). Online synchronous language learning: SLMS over the internet. Innovate: Journal of Online Education, 3(3).

Wankel, C. (Ed.) (2010). Cutting-edge social media approaches to business education: Teaching with Linkedln, Facebook, Twitter, Second Life, and Blogs. Charlotte, NC: Information Age Publishing, Inc.

Ward, J. (2010). The Avatar Lecturer: Learning \& Teaching in Second Life. Marketing Intelligence \& Planning, 28(7), 862-881. http://dx.doi.org/10.1108/02634501011086463

Warschauer, M., \& Kern, R. (2000). Network-based language teaching: Concepts and practice. New York, NY: Cambridge University Press.

Warschauer, M., \& Meskill, C. (2000). Technology and second language learning. In J. Rosenthal (Ed.), Handbook of undergraduate second language education (pp. 303-318), Mahwah, NJ: Lawrence Erlbaum Associate, Inc.

Yahaya, R. A. (2007). Blended virtual reality technology in the classroom. MEDC, 1, 57-69. 


\section{Appendix A}

\section{Sample F2F Observation Field Notes}

\section{Date: February, 2012}

Location: a classroom at a southern central university in the United States

Start of the session: the teacher enters the class, welcomes the students and asks them if they have anything they want to share with the rest of the students. One of the students shares her interesting experience in an ELI class about how raising your thumb means something completely different in some cultures and how insulting it can be. The class instructor reviews the last topic by asking some questions and using her slides she starts teaching the second chapter of the required book for the course.

The instructor is demonstrating how by using visuals you can teach vocabulary to non-native speakers. She says a word in Farsi. Obviously nobody knows what it means. She repeats it many times and explains what she means in different ways in Farsi. Nobody can guess. She takes out a key from under her desk and shows it to the students and repeats the word. Everybody laughs and says "key".

Throughout the session the instructor is trying to actively involve the students by asking them what they think about different topics and concepts covered during this particular session.

\section{Seating arrangement:}

Students are sitting in groups of 4-5 at tables scattered throughout the classroom. There are 45 students present and 3 absent. The teacher is standing at her podium and walking through the class every now and then.

Break: Since it is a 50 minute class, there is no break.

\section{Student activities:}

Students are put into groups to either agree or disagree with letting language learners' use their mother tongue in a main stream class. First they discuss it in smaller groups and then the class is divided into two groups for whole class discussion on the topic.

Also to show how important it is for both the native and the non-native speaker to be actively involved in a communication to keep it going, the instructor asks the students to pick up a partner and asks one of them to speak constantly for one minute and the other one just to listen with no feedback, neither verbal or non-verbal. The whole class gets busy (obviously loud!) and the instructor asks them to stop after one minute. Then she asks some of the students who did the speaking part how they felt when their partners just looked at them blankly giving them no indication of following.

Students have obviously enjoyed the activity and are still talking about it even after the class is done with it.

End of the session: The instructor wraps up the session by reminding the students not to forget to do an online discussion board which would be open soon and that next session they would still continue with chapter 2 . 


\section{Appendix B \\ Sample SL Observation Field Notes}

Date: February, 2012

Location: Glasscock (a SL TAMU) SLURL: http://maps.secondlife.com/secondlife/Glasscock/40/61/27

Start of the session: Students are sitting in groups of 8 . One is a graduate student and the other 7 are undergrads. They are talking about advantages and disadvantages of using SL in a class with language learners. The graduate student mainly leads the conversation and the undergraduate students are actively involved in the discussion. The graduate student is using voice and all undergraduate students are using voice to converse.

Seating arrangement: It is a class by ocean with slides and video clips related to the topic of the discussion and course materials. There are also many games, and pictures and video clips not directly or even indirectly related to the course material or discussion topic scattered everywhere. Students have picked to sit in a specific area with a couple of chairs. (see Figure 3 showing the Middle of the session where students are still discussing the article and the video clip they were assigned for this activity and discussing how SL can be applied to help language learners).

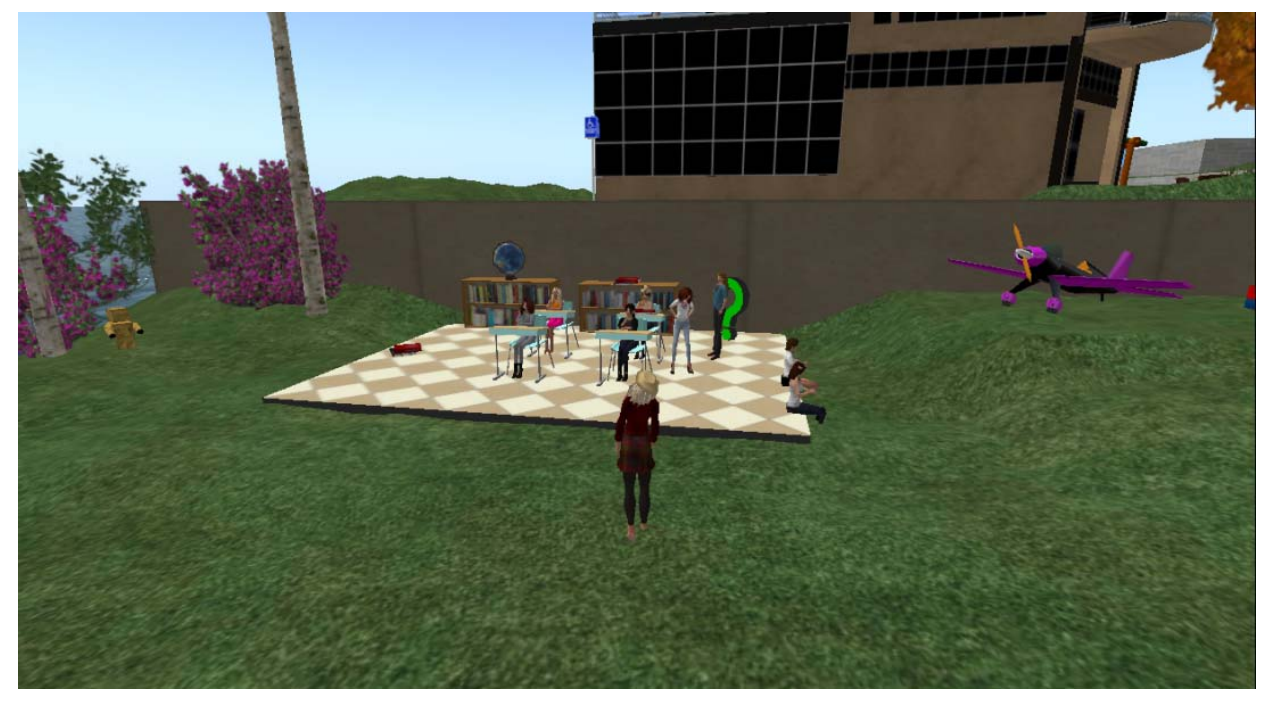

Figure 3. Caddy Shack Seating Arrangement.

Break: There was no break

Student activities: In this particular meeting they are just discussing the assigned article and the video clip on how SL can be used to help language learners.

End of the session: At the end of the one hour and thirty minutes session, the group leader wraps up the discussion and thanks the students for attending the meeting and helping with the discussion and reminds them of the next activity and meeting. 


\section{Appendix C}

\section{Interview questions}

1. What do you like about using eLearning as a student in your INST 462 class?

2. What don't you like about using ELearning as a student in your INST 462 class?

3. What do you like about using Second Life as a student in your INST 462 class?

4. What don't you like about using Second Life as a student in your INST 462 class?

5. What do you like about being taught in a face-to-face class in your INST 462 class?

6. What don't you like about being taught in a face-to-face class in your INST 462 class?

7. What do you like about using eLearning as a student in general?

8. What don't you like about using eLearning as a student in general?

9. What do you like about using Second Life as a student in general?

10. What don't you like about using Second Life as a student in general?

11. What do you like about being taught in a face-to-face class in general?

12. What don't you like about being taught in a face-to-face class in?

13. If you are asked to rank these three teaching modes (eLearning, face-to-face and Second Life) from 1(the best) to 3 (the worst), how would you rank them as a student?

14. If you can choose, would you choose to have only one of these teaching modes, two or three? Which one(s)?

15. What technical issues, if any, did you have when using eLearning?

16. What technical issues, if any, did you have when using second life?

17. Do you see any benefit in combining face-to-face, eLearning and Second Life? Why?

18. Do you as a future teacher think Second Life can help you teach your ESL students? Why?

19. Do you as a future teacher think Second Life in any ways can help you teach your students? Why?

20. What was your biggest challenge in using Second Life for INST462? 